\title{
Genetic Characterization of the Northern Shrimp, Pandalus borealis, in the Northwest Atlantic Using Electrophoresis of Enzymes
}

\author{
J.-M. Sévigny and L. Savard \\ Ministère des Pêches et des Océans, Institut Maurice-Lamontagne, 850 route de la Mer \\ C.P. 1000, Mont-Joli, Québec, Canada G5H $3 Z 4$ \\ and \\ D. G. Parsons \\ Science, Oceans and Environment Branch, Department of Fisheries and Oceans \\ P. O. Box 5667, St. John's, Newfoundland, Canada A1C 5X1
}

\begin{abstract}
The genetic variability of the northern shrimp, Pandalus borealis, collected in the Saguenay Fjord, in six areas of the Estuary and the Gulf of St. Lawrence, and in two areas off the Labrador coast was assessed using eight enzymatic loci. Males, primiparous and multiparous females were sampled at all but one site in order to determine if gene frequencies within these regions of the Northwest Atlantic are temporally stable. For this protandrous species, variation of the genetic characteristics on a geographic scale and among maturity stages was largely determined by the variation occurring at the $E S T^{*}, H K-1 *$ and to a lesser extent at the $H K-2 *$ loci. The other loci did not vary significantly either on geographic or temporal scales. Deviations from HardyWeinberg expectations, all of them due to deficits in heterozygotes, were observed mainly at the same three loci and the number of deviations increased when males, primiparous and multiparous females were pooled. A cluster analysis of genetic distance did not reveal geographic patterns in the clustering of the samples. Although some rare private alleles were detected in the Gulf of St. Lawrence samples, the data suggest that gene flow is extensive across the study area.
\end{abstract}

Keywords: allozyme, genetics, Northwest Atlantic, Northern shrimp, Pandalus borealis, population structure

\section{Introduction}

The northern shrimp, (Pandalus borealis) is a circumboreal protandric hermaphrodite crustacean found and exploited in the high latitudes of the Atlantic and the Pacific Oceans (Ivanov, 1972; Shumway et al., 1985). In the Northwest Atlantic, it is distributed from the Gulf of Maine to the Davis Strait (Ivanov, 1972) and in the St. Lawrence system the species can be found from West Newfoundland to the Saguenay Fjord. Exploited aggregations are found in the Estuary and the Gulf of St. Lawrence, in the Gulf of Maine and on the Scotian Shelf, along the east coast of Newfoundland and Labrador and in the Davis Strait (Parsons and Frechette, 1989; Lambert et al., MS 1998; Parsons et al., MS 1999).

Despite the economic importance of the northern shrimp, only a few studies have attempted to describe its population genetic structure. These studies show that shrimp occurring in seas that are geographically far apart such as the Barents and the Bering seas, the Sea of Japan and the Gulf of St. Lawrence are clearly genetically differentiated from each other (Kartavtsev et al., 1991; Kartavtsev et al., 1993; Kartavtsev, 1994; Jónsdóttir et al., 1998). It is worth mentioning however, that the taxonomic status of the northern shrimp is under debate. Indeed, Squires (1992) recognized the Pacific form as a species (Pandalus eous) rather than a subspecies of $P$. borealis, while Sokolov (1997) argued that most of the morphological features considered by Squires reflected within species variability and that the subspecies ranking should be retained. The possibility that some of the differences observed in previous studies might have been between species rather than within species cannot be excluded until the taxonomic status of the northern shrimp is clarified. Since the present study does not provide additional 
relevant information, this issue will not be considered further.

The possibility of observing genetically differentiated populations over shorter distances is not well established. Indeed, while some studies have shown that populations of shrimp were homogeneous within seas and that this homogeneity appears to be stable through time (Kartavtsev et al., 1991; Kartavtsev et al., 1993; Kartavtsev, 1994), another has detected differences in allelic frequencies at allozyme loci between shrimp collected inshore and offshore off Iceland and in the Denmark Strait (Jónsdóttir et al., 1998). Our studies to date of the genetic structure of the northern shrimp have been largely restricted to the Gulf of St. Lawrence. These preliminary studies suggest the existence of heterogeneity in allelic frequencies among samples in this area (Savard, MS 1989; Savard et al., MS 1993; Sévigny, 1994).

An understanding of the geographical stock structuring is critical to the development and implementation of management and conservation measures of exploited species. Indeed, management of the fishery of a marine species is based on the definition of management units, which should correspond to stocks (or populations) with particular patterns of recruitment, growth and mortality. The assessment of the population genetic structure of exploited species can thus provide valuable information on the interaction between populations and their resilience to exploitation and therefore, can influence the choice of resource conservation strategies (Carvalho and Hauser, 1995; Shaklee and Bentzen, 1998; Ward, 2000 for reviews). However, the life cycle of the northern shrimp is characterised by the presence of a larval stage that may last for $2-4$ months. Since the circulation patterns prevailing in the Northwest Atlantic favour widespread dispersion (Drinkwater and Mountain, 1997; Fig. 1), we can hypothesise that genetic differentiation will be weak for this species in the Northwest Atlantic.

The goal of the present study was to describe genetic variability of the northern shrimp in the St. Lawrence system and along the Labrador coast, to determine if the genetic variation patterns observed suggest the existence of genetically differentiated populations in Eastern Canada. The description of genetic variation presented in this study is based on allozyme loci and includes samples collected over a large geographic area. Males, primiparous and multiparous females were sampled at several sites in order to assess the importance of the temporal variability, since these maturity stages were assumed to represent different age groups (Shumway et al., 1985). Indeed, genetic difference on a geographic scale will indicate that populations are relatively isolated and self-recruiting if the difference observed is stable through time. By contrast, if temporal variation is important, the genetic difference observed among sites might be modified between generations if genetically different cohorts are recruited (David et al., 1997; Li and Hedgecock, 1998). More specifically, the objectives of the present study were to determine if:

1) genetically isolated populations are present within the Gulf of St. Lawrence,

2) genetically isolated populations are present along the Labrador coast,

3 ) the populations from the Gulf of St. Lawrence are genetically isolated from those of the Labrador coast, and

4) the genetic characteristics described are temporally stable.

\section{Material and Methods}

\section{Sampling and sample preservation}

Samples were collected within commercially exploited shrimp aggregations in the Estuary and the Gulf of St. Lawrence as well as in Hawke and Hopedale Channels on the Labrador coast during the routine annual surveys conducted by the Department of Fisheries and Oceans, Canada. Samples were also collected in the Saguenay Fjord, which sustains a peripheral unexploited population. Samples were collected using a bottom trawl from August to September 1990 (Fig. 1). They were collected in one tow at the Rimouski site, two tows at Pointe-des-Monts, Sept-Îles, North and South Anticosti sites and, over much larger areas (12 tows) in the Esquiman Channel, Hawke Channel and Hopedale Channel. Samples from the Saguenay Fjord were collected with baited traps during the summer 1990 in the Baie des Ha! Ha!, at Sainte-Rose-du-Nord and at Baie Trinité (Sévigny, 1994). For the present study, these three sampling stations are considered part of the same site.

Sampled shrimp were classified into three maturity stages assumed to represent three different age groups: males, primiparous and multiparous females (Table 1). Individuals were sexed from the characteristics of the first pleopod endopodite (Rasmussen, 1953). The separation between primiparous and multiparous females was based on the presence or absence of sternal spines located on the midventral face of the first four abdominal segments (McCrary, 1971). Specimens were dissected on board and samples of abdominal muscle and 


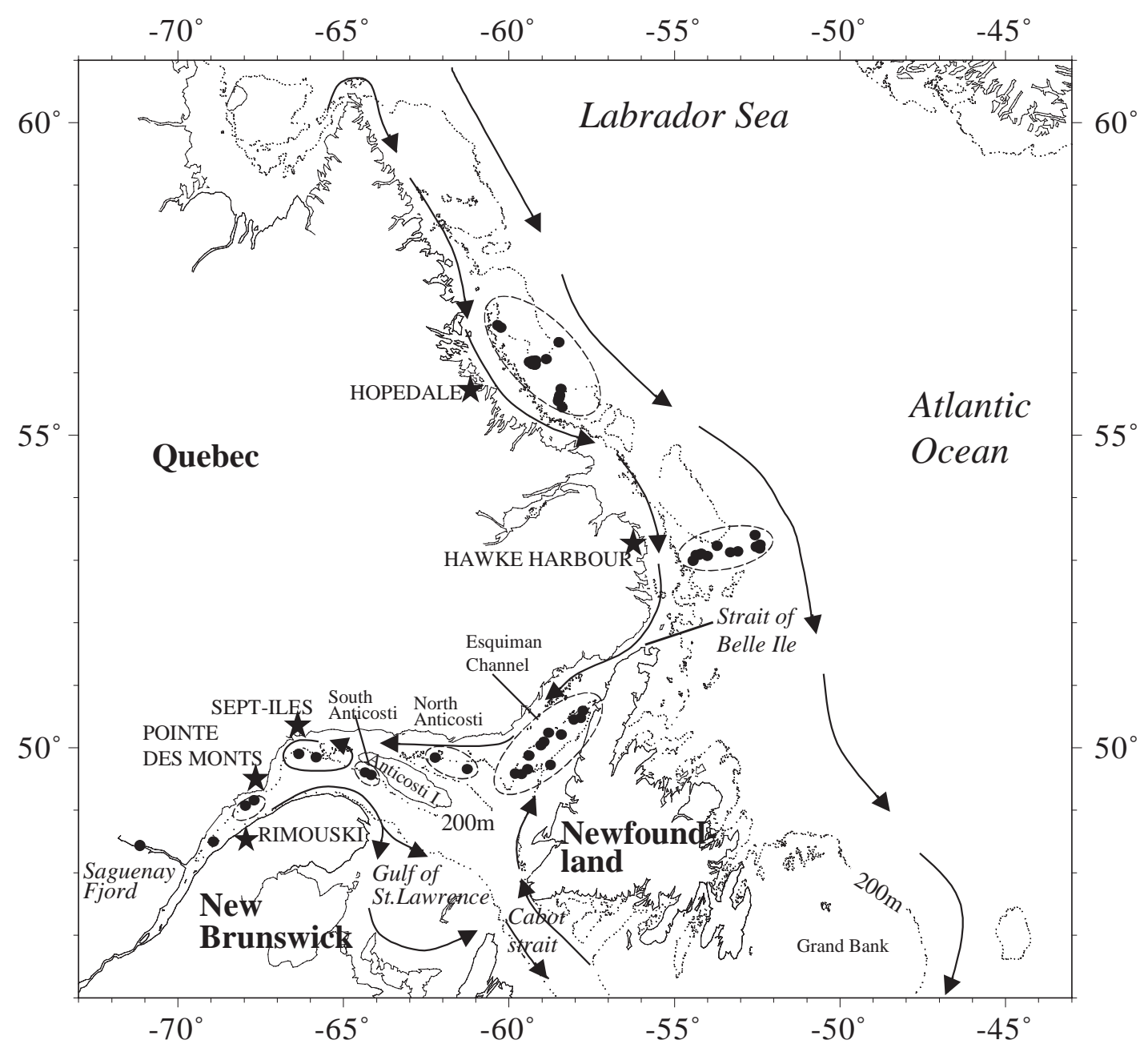

Fig. 1. Location of the sampling sites in the Gulf of St. Lawrence and east of the Newfoundland-Labrador coast. Samples encircled by broken lines were considered to be part of the same sampling site. The general circulation patterns of the Northwest Atlantic are also indicated.

hepatopancreas tissue were frozen either in liquid nitrogen or in dry ice and transported to the Maurice Lamontagne Institute, Quebec, where they were transferred to an ultracold freezer $\left(-80^{\circ} \mathrm{C}\right)$ pending genetic analyses. Whole specimens from the Esquiman Channel and of the Saguenay Fjord where frozen on board in liquid nitrogen and dry ice, respectively. They were dissected in the laboratory prior to electrophoresis analyses.

\section{Allozyme analysis}

Tissue homogenates were prepared according to the procedure described in Roby et al. (1991). All allozymes were assayed on cellulose acetate gels using the technique of Hebert and Beaton (1989), except for esterases which were studied on discontinuous polyacrylamide slab gels (method adapted from Ornstein, 1964). Enzyme activities were visualised according to the standard staining procedure described by Murphy et al. (1990). All staining solutions other than esterases were incorporated in a $1 \%$ agar overlay. The bands of activity which were consistently detected in the hepatopancreas extracts without specific substrate and with MTT (3-(4,5-Dimethylthiazol-2-yl)-2,5-diphenyltetrazolium bromide) and PMS (Phenazine methosulfate) were tentatively attributed to the activity of tetrazolium reductase (TR). Specimens of known genotype were used as standards on every gel to assess both the quality of the electrophoretic separation and to ensure the accuracy of allele identification. Uncommon alleles at each locus were re-run simultaneously to ascertain their classification. 
TABLE 1. Number of northern shrimp (Pandalus borealis) collected for allozyme analyses.

\begin{tabular}{lcrrr}
\hline \hline & \multicolumn{3}{c}{ Maturity stage } \\
\cline { 2 - 4 } Sampling Site & Male & \multicolumn{2}{c}{ Female } & \\
\cline { 2 - 4 } Sarimiparous & Multiparous & Total \\
\hline Saguenay Fjord & 30 & 34 & 225 & 289 \\
Rimouski & 70 & 3 & 7 & 80 \\
Pointe-des-Monts & 50 & 50 & 50 & 150 \\
Sept-Iles & 50 & 50 & 50 & 150 \\
South Anticosti & 50 & 50 & 50 & 150 \\
North Anticosti & 50 & 50 & 50 & 150 \\
Esquiman Channel & 13 & 58 & 50 & 121 \\
Hawke Channel & 50 & 49 & 21 & 120 \\
Hopedale Channel & 47 & 48 & 48 & 143 \\
\hline
\end{tabular}

\section{Statistical analysis}

Allele frequencies and other population genetic statistics such as the $F$ statistics $\left(F_{I S}\right.$ and $\left.F_{S T}\right)$ observed and expected heterozygosities were calculated for each locus using the Biosys-1 computer program of Swofford and Selander (1989). This program was also used to test for deviations from Hardy-Weinberg expectations at all sites using the chi-square $\left(\chi^{2}\right)$ test of goodness-of-fit. When more than two alleles were observed at a locus, genotypes were pooled into three classes representing the homozygotes for the most common allele, the heterozygotes for the most common allele and all other genotypes. Tests of conformance to Hardy-Weinberg equilibrium were carried out for each maturity group within sites and for all the maturity stages pooled at each site. These tests could not be performed for the $G P I^{*}$ and $P G M^{*}$ loci for any of the maturity stages and for the maturity stages pooled due to the low variability detected at these two loci. Furthermore, these could not be performed at the Rimouski site for the primiparous and the multiparous females since only 3 and 7 individuals respectively were collected at this site (Table 1).

Differences in allelic frequencies between males, primiparous and multiparous females within sites and heterogeneity in allelic frequencies among sampling sites within the Gulf of St. Lawrence, within the Labrador Sea and across the study area were tested for significance using the Monte Carlo randomization procedure (Roff and Bentzen, 1989) as implemented in the REAP software (McElroy et al., 1992). The advantage of this procedure is that it allows testing without grouping rare alleles. Despite this procedure, comparison of allelic frequencies among maturity stages could not be carried out at the $G P I^{*}$ and $P G M^{*}$ loci because the variability detected at these loci was too low. Furthermore, the comparison among maturity groups could not be carried out at the Rimouski site for any loci because of the low number of primiparous and multiparous females collected at this site. Sequential Bonferroni tests were used to maintain the overall significance level $\alpha=0.05$ as recommended by Rice (1989).

The $F$ statistic analysis was used to partition the genetic variance into that occurring within populations $\left(F_{I S}\right)$ and that occurring between populations $\left(F_{S T}\right)$. A chi-square test (Workman and Niswander, 1970) was used to evaluate the null hypothesis of $F_{S T}=0$. In this test, the $\chi^{2}$ values were calculated according to the equation: $2 n F_{S T}(K-1)$ with degrees of freedom equal to $(K-1)(S-1)$. Similarly, the significance of $F_{I S}$ was tested using the equation: $n\left(F_{I S}\right)^{2}(K-1)$ with degrees of freedom equal to $(K(K-1)) / 2$. In these equations $n$ is the total number of individuals sampled, $K$ is the number of alleles at the locus and $S$ represents the number of populations sampled.

Gene flow was estimated from Wright's fixation index (Wright, 1978) according to the formula:

$$
F_{S T}=1 /\left(1+4 N_{e} m\right)
$$

where $m$ is the migration rate and $N_{e}$ is the effective number of individuals.

Absolute differentiation between populations was estimated using Nei (1978) unbiased and Cavalli-Sforza and Edwards (1967) chord genetic distances.

\section{Results}

Genetic variability was detected at eight enzymatic systems, five of which were better resolved in the 
hepatopancreas (Table 2). The number of alleles observed at these loci varied from 2 to 6 (Table 2). Genetic variability was the lowest at the GPI* locus that was variable in only two sites (Table 3 ). For this locus, only one heterozygous individual was detected at the Rimouski site and two at Esquiman Channel. This locus was analysed despite its low variability for comparison with previous studies (Kartavtsev et al., 1991; Kartavtsev et al., 1993; Kartavtsev, 1994; Jónsdóttir et al., 1998). Genetic variability was also low at the PGM* locus with observed heterozygosities varying between 0.007 for the pooled maturity stages in Saguenay Fjord and 0.063 for the primiparous females in the Hopedale Channel (Table 3). When the maturity stages were considered separately, the lowest value of mean observed heterozygosity was 0.164 for the primiparous females collected at the South Anticosti site while the highest value of 0.258 was estimated for the males from Hawke Channel (Table 3). Mean observed heterozygosity evaluated for all the maturity stages pooled varied from 0.204 for the South Anticosti site to 0.242 for the Esquiman Channel site. There was no apparent trend in heterozygosity change among maturity stages within sites or on the geographical scale (Table 3 ).

\section{Conformance to Hardy-Weinberg expectations}

A general pattern emerged when deviation from Hardy-Weinberg expectations was considered for each maturity stage. Indeed, for all three stages, significant deviations were observed mainly at the $E S T^{*}, H K-1^{*}$ and $H K-2 *$ loci and all deviations (eight for males, six and nine for primiparous and multiparous females respectively) were caused by deficits in the number of heterozygotes (Table 4).
Deviations from Hardy-Weinberg were more frequently observed (17 site-loci) when all the maturity stages were pooled. As was the case for maturity stage considered individually, the significant deviations were largely restricted to the $E S T^{*}$ (all sites) and $H K-I^{*}$ (five sites) loci. In addition, deviations were observed at the $H K-2 *$ (two sites) and $M D H^{*}$ (one site) loci (Table 4).

The $F$-statistics (Wright, 1978) were also used to test for genetic differentiation. The values of $F_{I S}$, indicating the within-sample genetic structuring, differed significantly from zero at the EST*, $H K-1^{*}$ and $H K$ $2 *$ loci for maturity stages pooled. All values were positive indicating a deficit in heterozygotes (Table 5).

\section{Genetic variability among maturity stages within sites}

A total of 48 randomisation tests were carried out. Of these, significant difference was detected at the $T R^{*}$ locus in Saguenay Fjord $\left(\chi^{2}=8.91 ; P=0.011\right)$ and North Anticosti samples $\left(\chi^{2}=6.22 ; P=0.038\right)$, at the $H K-2 *$ locus at Pointe-des-Monts $\left(\chi^{2}=11.05 ; P=0.002\right)$, at the $E S T^{*}$ locus $\left(\chi^{2}=24.99 ; P=0.0000\right)$ and $H K-1 *\left(\chi^{2}=\right.$ $15.27 ; P=0.004)$ in Hawke Channel and at the $M D H^{*}$ locus $\left(\chi^{2}=8.54 ; P=0.011\right)$ in Hopedale Channel. When the Bonferroni procedure (Rice, 1989) was applied for each site, differences remained significant for the $E S T^{*}$, $H K-1 *$ and $H K-2 *$ loci.

\section{Geographic variation}

Significant heterogeneity in allelic frequencies was observed among sites at the scale of the Northwest Atlantic as well as within each of the two large scale areas investigated, the Gulf of St. Lawrence and the Labrador Sea (Table 6). It is worth noting that all

TABLE 2. Enzymatic systems used in the genetic characterisation of the northern shrimp, Pandalus borealis. The number of observed alleles corresponds to those detected in the samples. $\mathrm{H}=$ hepatopancreas, $\mathrm{M}=$ muscle.

\begin{tabular}{|c|c|c|c|c|}
\hline Enzyme & E.C. No. ${ }^{\mathrm{a}}$ & $\begin{array}{c}\text { Observed } \\
\text { Loci }\end{array}$ & Tissue & $\begin{array}{c}\text { No. of } \\
\text { Observed } \\
\text { Alleles }\end{array}$ \\
\hline Esterase (EST) & 3.1 .1 & 1 & $\mathrm{H}$ & 6 \\
\hline Glucose-6-phosphate isomerase (GPI) & 5.3.1.9 & 1 & M & 2 \\
\hline \multirow[t]{2}{*}{ Hexokinase (HK) } & 2.7.1.1 & $H K-1$ & $\mathrm{H}$ & 4 \\
\hline & & $H K-2$ & $\mathrm{H}$ & 2 \\
\hline Malate dehydrogenase (MDH) & 1.1.1.37 & 1 & M & 2 \\
\hline Phosphogluconate dehydrogenase (PGDH) & 1.1.1.44 & 1 & $\mathrm{H}$ & 3 \\
\hline Phosphoglucomutase (PGM) & 5.4.2.2 & 1 & M & 3 \\
\hline Tetrazolium reductase (TR) & & 1 & $\mathrm{H}$ & 2 \\
\hline
\end{tabular}

a E.C. No. = classification based on Enzyme Committee, International Union of Biochemistry. 


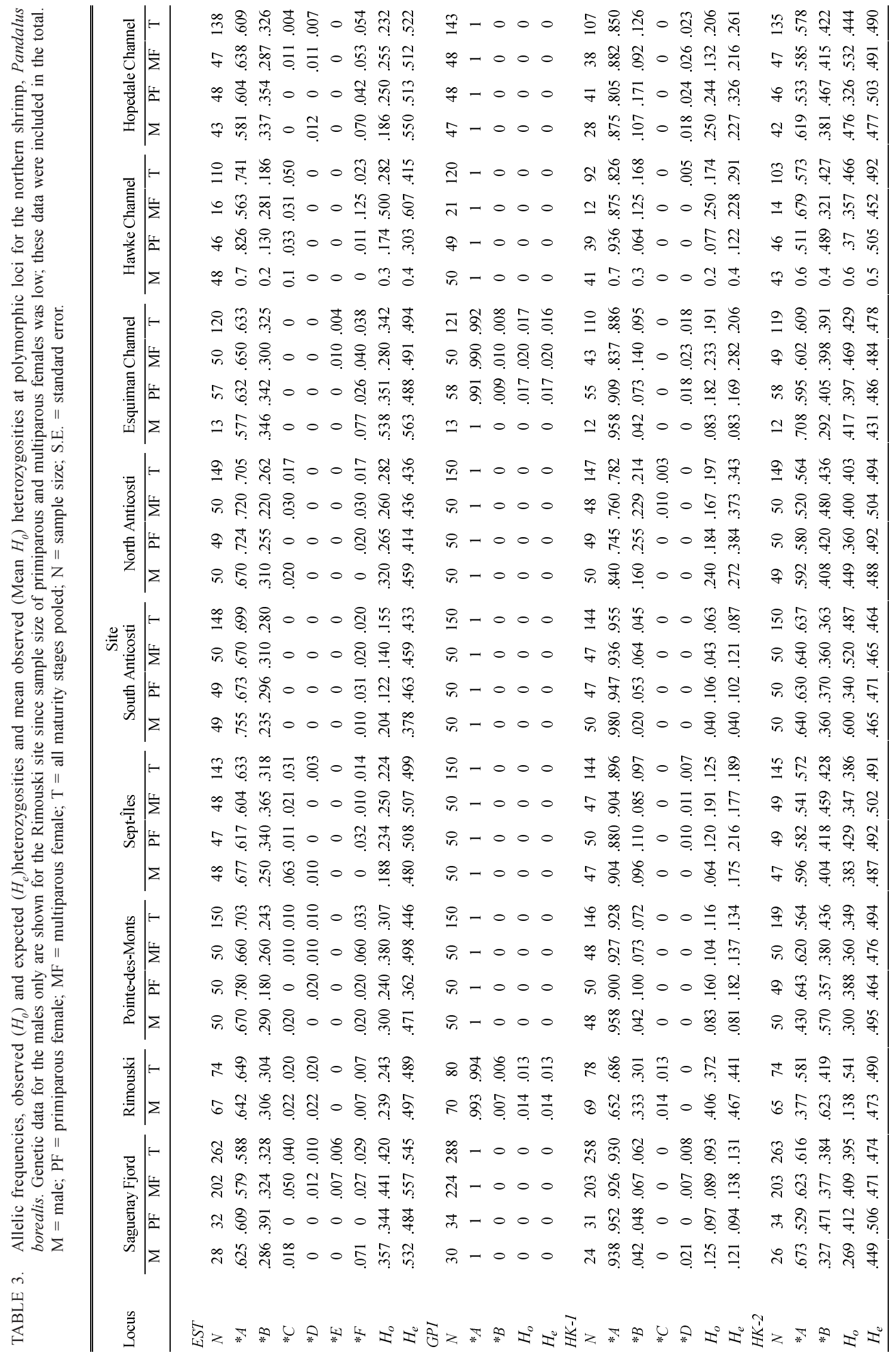




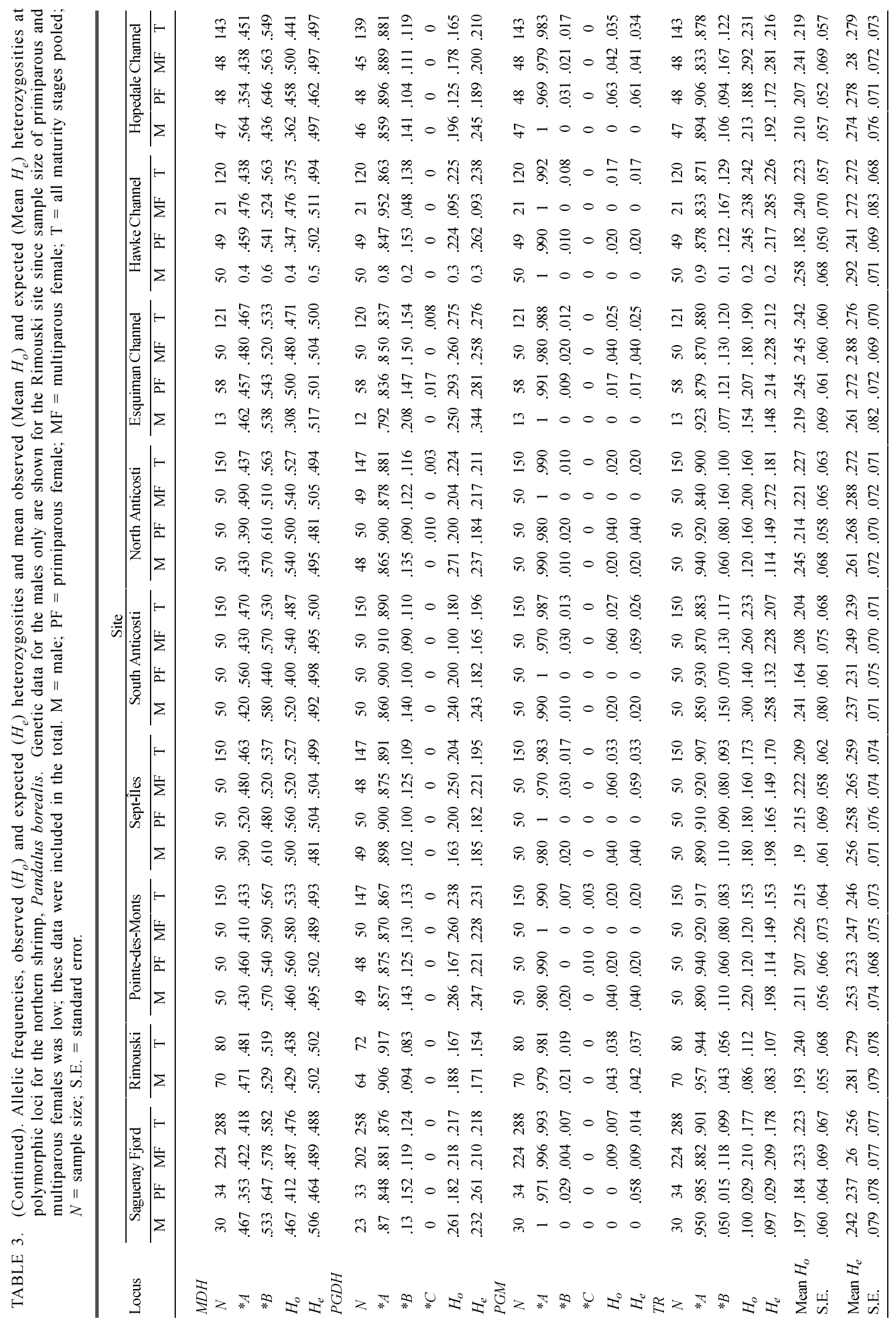




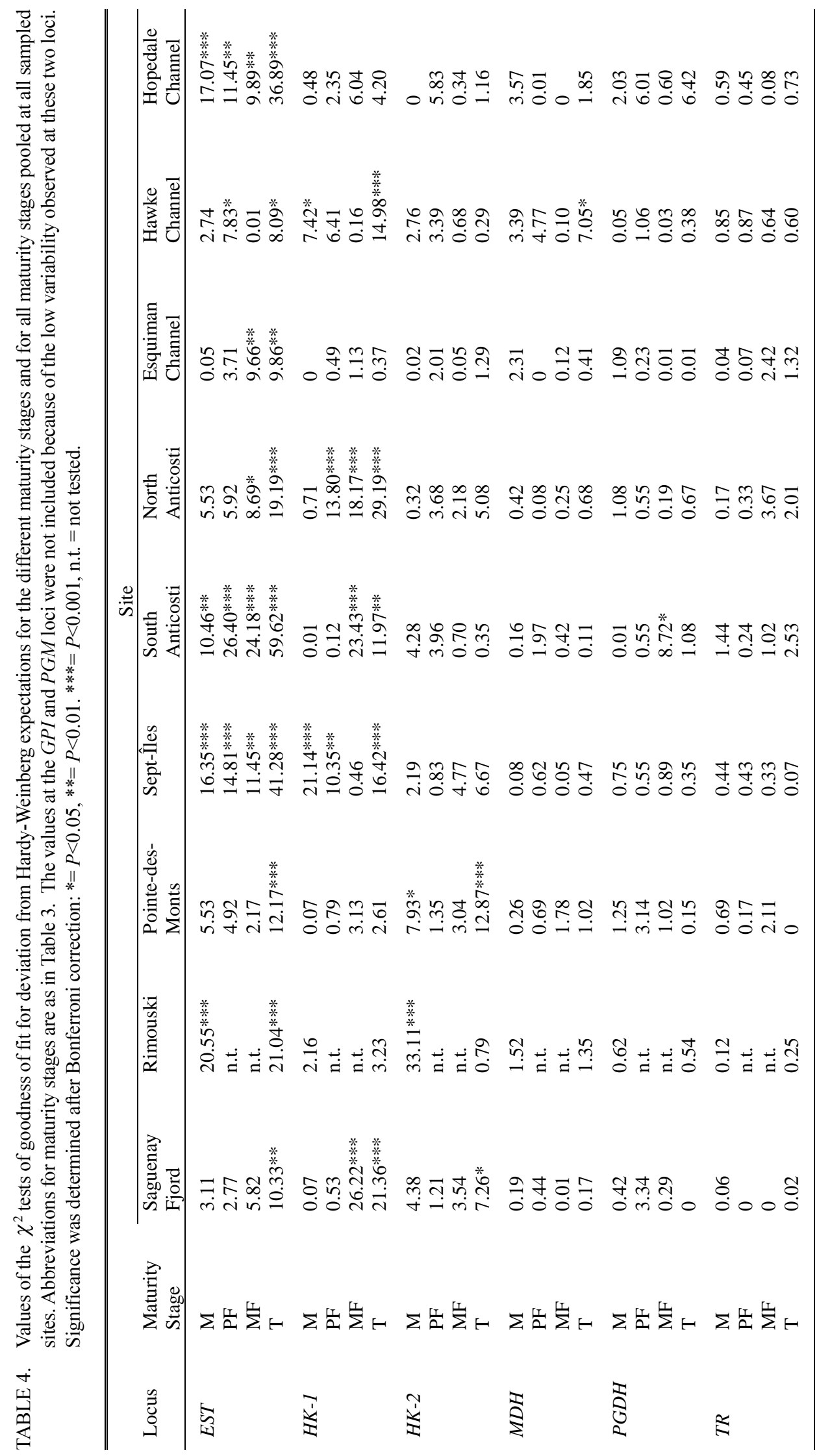


TABLE 5. F statistics calculated for each locus and estimated values of the number of Pandalus borealis migrants per generation $\left(N_{e} m\right)$ for all maturity stages pooled. * = $P<0.05$

\begin{tabular}{lclr}
\hline \hline Locus & $F_{I S}$ & $F_{S T}$ & $N_{e} m$ \\
\hline$E S T$ & $0.417^{*}$ & $0.010^{*}$ & 25 \\
$G P I$ & -0.007 & 0.005 & 50 \\
$H K-1$ & $0.259^{*}$ & $0.052^{*}$ & 5 \\
$H K-2$ & $0.103^{*}$ & 0.002 & 125 \\
$M D H$ & 0.040 & 0.002 & 125 \\
$P G D H$ & 0.013 & 0.004 & 62 \\
$P G M$ & 0.017 & 0.001 & 250 \\
$T R$ & -0.017 & 0.005 & 50 \\
Mean over loci & 0.155 & 0.010 & 25 \\
$\begin{array}{l}\text { Mean over loci } \\
\text { excluding EST }\end{array}$ & 0.050 & 0.003 & 83 \\
and $H K-1$ & & & \\
\hline
\end{tabular}

differences in allelic frequencies on the geographic scale were observed at the $E S T^{*}$ and $H K-1^{*}$ loci for some maturity stages and in some areas investigated. Indeed, in the Gulf of St. Lawrence, significant difference could be detected only at the $H K-1$ * locus for the males and at the $E S T^{*}$ and $H K-1 *$ loci for the pooled samples. In the Labrador Sea, differences were observed only at the $E S T^{*}$ locus for the males, primiparous females and maturity stages pooled. At the scale of the Northwest Atlantic, differences were detected at the $E S T^{*}$ locus for the males and the maturity stages pooled and at the $H K-1$ * for the males, primiparous females and for the pooled maturity stages. No difference could be detected for the multiparous females at any locus in any of the studied area (Table 6). Values of $F_{S T}$, an index measuring the degree of differentiation among sub-populations, ranged from 0.001 to 0.052 for the maturity stages pooled and were significantly different from zero at the $E S T^{*}$ and $H K-1 *$ loci only (Table 5).

Nine alleles in low frequency $(\leq 0.01$ at some sites after pooling the maturity stages) were detected (Table $3)$. Of these alleles, four $\left(E S T^{*} C, E S T^{*} D, H K-1 * D\right.$, $P G M^{*} B$ ) were present in one or more sites of both the St. Lawrence system and the Labrador Sea. The other five $\left(E S T^{*} E, G P I^{*} B, H K-1^{*} C, P G D H^{*} C, P G M^{*} C\right)$ were private to the St. Lawrence system. They were often detected at sites separated by large geographic distances and were absent at intermediary sites.
Absolute differentiation among the sampling sites was weak. Unbiased Nei's genetic distances for pooled maturity stages ranged from 0.000 to 0.011 while that of Cavalli-Sforza and Edwards genetic distances varied from 0.034 to 0.105 (Table 7). UPGMA cluster analysis of Cavalli-Sforza and Edwards genetic distances calculated for each maturity stage and for all maturity stages pooled showed that genetic differences that exist among shrimp samples did not reveal geographic patterns in the clustering of the samples (Fig. 2). For example, the two samples from the Labrador Sea appeared to be more similar to some samples from the Gulf of St. Lawrence than they were to each other. It thus seemed that samples separated by large geographic distances were less different from each other than they were from geographically contiguous samples. The correspondence between genetic and geographic distances did not improve when the analyses were carried out without the $E S T^{*}$ and $H K-1 *$ loci (results not shown).

\section{Gene flow estimation}

Values of $N_{e} m$ calculated at each locus were high except for $H K-1 *$ (Table 5). An overall value of 25 was estimated from $F_{S T}$ mean value calculated over all loci. The lowest values of $N_{e} m$ were observed at the EST* and $H K-1 *$ loci. However, disequilibrium of genotypic proportion as well as significant differences in allelic frequencies among maturity stages were observed at 


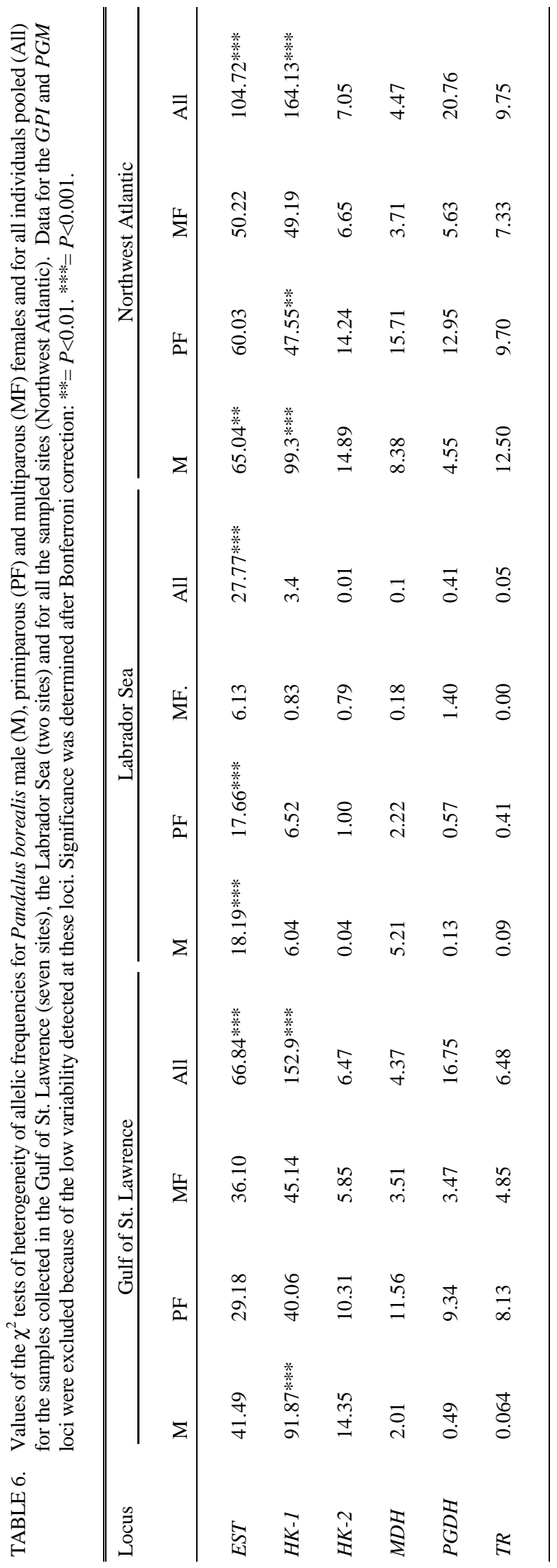


TABLE 7. Matrices of genetic distances between samples for all Pandalus borealis maturity stages pooled over all loci. Nei (1978) genetic distances are shown above diagonal and Cavalli-Sforza and Edwards (1967) chord distances are shown below the diagonal.

\begin{tabular}{lccccccccc}
\hline \hline Populations & 1 & 2 & 3 & 4 & 5 & 6 & 7 & 8 & 9 \\
\hline 1 Saguenay Fjord & --- & .010 & .001 & .000 & .001 & .005 & .000 & .005 & .001 \\
2 Rimouski & .094 & --- & .009 & .006 & .011 & .001 & .007 & .005 & .005 \\
3 Pointe-des-Monts & .047 & .088 & --- & .000 & .001 & .002 & .001 & .001 & .001 \\
4 Sept-Iles & .034 & .076 & .043 & --- & .001 & .002 & .000 & .002 & .000 \\
5 South Anticosti & .063 & .105 & .046 & .056 & --- & .005 & .000 & .003 & .002 \\
6 North Anticosti & .072 & .056 & .060 & .052 & .072 & --- & .002 & .000 & .001 \\
7 Esquiman Channel & .064 & .099 & .064 & .061 & .056 & .070 & --- & .003 & .000 \\
8 Hawke Channel & .063 & .080 & .059 & .049 & .077 & .042 & .076 & --- & .002 \\
9 Hopedale Channel & .052 & .084 & .054 & .044 & .062 & .062 & .046 & .063 & --- \\
\hline
\end{tabular}

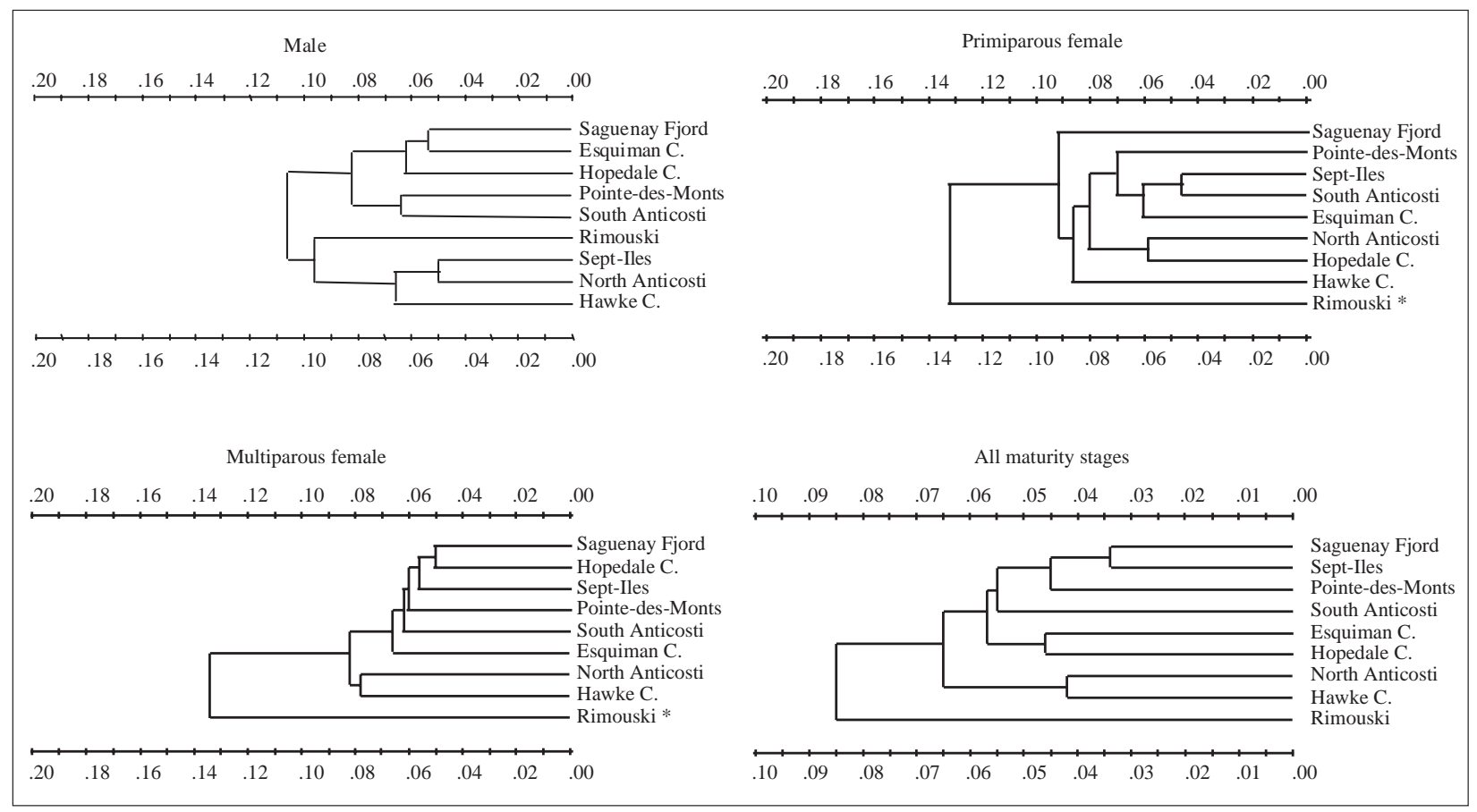

Fig. 2. Dendrogram, constructed from Cavalli-Sforza and Edwards (1967), showing genetic distance summarising the genetic relationship among the nine northern shrimp samples from the Gulf of St. Lawrence and the Labrador Sea. (* very small sample sizes).

these loci in many samples. The possibility that these changes could result from environmental effects cannot be ruled out. Therefore, the mean $N_{e} m$ was recalculated without taking into account these two loci. When these two loci are omitted, the mean $N_{e} m$ increased to 83 (Table 5).

\section{Discussion}

The present study differs from previous ones (Kartavtsev et al., 1991; Kartavtsev et al., 1993; Kartavtsev, 1994; Jónsdóttir et al., 1998) as eight loci from either the abdominal muscle tissue or the 
hepatopancreas were used to assess genetic variability of the northern shrimp, P. borealis in the Northwest Atlantic. Using the hepatopancreas allowed the resolution of five additional polymorphic loci (Table 2). The $G P I^{*}, P G M^{*}$ and $M D H^{*}$ loci were the only ones that had been used in previous studies on northern shrimp. In this study the GPI* locus also showed the lowest variability of all as only three heterozygous individuals were detected in the analyzed samples. Variability at the $P G M^{*}$ locus was also low in all samples.

There are some differences in the number of alleles detected at the three loci common to studies carried out in the North Atlantic. In the Barents Sea, Kartavtsev et al. (1991) detected two alleles at the GPI*, the $P G M^{*}$ and at the $M D H^{*}$ loci. In the present study, two alleles were detected at the $G P I^{*}$ and the $M D H^{*}$ loci but three were detected at the $P G M^{*}$ locus (Table 2 and 3 ). Such differences are not surprising given the distance separating the study areas and the fact that shrimp from different seas are genetically differentiated (Kartavtsev et al., 1991; Kartavtsev et al., 1993; Kartavtsev, 1994). Jónsdóttir et al. (1998) detected four alleles at the GPI* locus and six at the $P G M^{*}$ and $M D H^{*}$ loci in samples collected in the Denmark Strait and from inshore and offshore Iceland. Various factors may explain the discrepancies between our results and previous results. Indeed, Jónsdóttir et al. (1998) assessed genetic variability using starch gel electrophoresis and isoelectric focusing, an electrophoretic separation technique based on protein isoelectric point differences (see Whitmore, 1990 for a review), while cellulose acetate was used in the present study. However, these differences may also indicate that genetic differentiation has taken place between Northwest (Gulf of St. Lawrence and the Labrador Sea) and Northeast Atlantic populations of northern shrimp. Additional studies will be necessary to assess the importance of the interaction between populations from both sides of the North Atlantic.

A general picture emerges from the present study. The changes in the genetic statistics such as deviation from Hardy-Weinberg expectations, differences among maturity stages and macrogeographic heterogeneity of allelic frequencies are almost exclusively the results of variation occurring at the $E S T^{*}$ and $H K-1 *$ loci. This observation applies even though the variability at most of the other loci is high enough to allow the detection of changes in the genetic characteristics of the species within maturity stages or with space. The fact that the pattern of variation detected at the EST* and
$H K-1 *$ loci differs from that detected at the other loci suggests that these two loci may not be neutral. Furthermore, it is also at these two loci that significant differences were observed between maturity stages at some sites, an indication that selection may be influencing the variability at these loci. However in the present study, the relevant factors generating the genetic variation observed at these two loci could not be identified. This study is not the first one that has observed such variation. For example, deviation from Hardy-Weinberg caused by deficit in heterozygotes was observed at an $E S T^{*}$ locus in the estuarine population of the mud crab (Macrophthalmus hirtipes) and was attributed to selection against the heterozygotes (Sin and Jones, 1983). Heterozygote deficiency was also observed at the EST*, HK-1 *, GPI* and PT-2* loci in the crab Trapezia digitalis (Huber, 1987) and in the spiny lobster (Panulirus marginatus) at the EST-3* and MPI* loci (Seeb et al., 1990). In this species, heterogeneity on the geographical scale as well as difference between years was detected at the EST-3* locus. Multilocus studies involving other types of molecular markers will be necessary to understand the dynamics of the $E S T^{*}$ and $H K-1 *$ loci in the northern shrimp.

When the $E S T^{*}$ and $H K-1 *$ loci are not taken into consideration for the above reasons, there are indications that gene flow may be important across the study area. Firstly, none of the other most variable loci $\left(H K-2^{*}, M D H^{*}, P G D H^{*}\right.$ and $\left.T R^{*}\right)$ has allowed the discrimination of differentiated populations at any of the geographical scales considered in this study; within the St. Lawrence system and the Labrador Sea and between these two systems. The variability detected at the $H K-2^{*}, M D H^{*}, P G D H^{*}$ and $T R^{*}$ loci should be sufficiently high to confer discrimination power to these loci. Secondly, gene flow $\left(N_{e} m\right)$ estimated from the mean $F_{S T}$ values is high (25) across the study area even when $E S T^{*}$ and $H K-1 *$ loci are included in the calculation. It is worth noting that the smallest $N_{e} m$ value (5) was observed at the $H K-1$ * locus. The value further increases to 83 when $E S T^{*}$ and $H K-1 *$ loci are not taken into account. Thirdly, among the nine low frequency alleles detected at different loci, four $\left(E S T^{*} C\right.$, $E S T^{*} D, H K-1{ }^{*} D, P G M^{*} B$ ) were present in one or more sites of both the St. Lawrence system and the Labrador Sea. The other five alleles $\left(E S T^{*} E, G P I^{*} B, H K-1{ }^{*} C\right.$, $P G D H^{*} C, P G M^{*} C$ ) were private to the St. Lawrence system. Although these may indicate restricted gene flow (Slatkin, 1985), they were often detected at sites separated by large geographic distances and were absent at intermediary or adjacent sites. Therefore, they 
may not have been detected at other sites or in the Labrador Sea because of inadequate sample size. Indeed, it has been estimated that a sample size of at least 754 individuals would be necessary to detect, with a probability of $95 \%$, all the alleles with frequencies of 0.01 present at a locus (Gregorius, 1980). The sample size is adequate for the St. Lawrence system if all sites are considered but is too small for the Labrador Sea sites. A mean of 1064.9 individuals (S.D. $=26.6)$ were analyzed in the St. Lawrence system when all loci and sites were considered while the mean for the Labrador Sea sites are only 237.0 (S.D. = 36.9). In any case, except for the distribution of these private alleles, our results are in general agreement with those obtained in previous studies that have shown homogeneity within seas (Kartavtsev et al., 1991; Kartavtsev, 1994). However, the possibility that differentiation can occur on a smaller scale in other oceans cannot be excluded since Jónsdóttir et al. (1998) have shown that some differentiation has taken place in the Northeast Atlantic.

The lack of genetic differentiation over large geographic distance is not unusual for marine species (Shaklee and Bentzen, 1998; Bohonak, 1999; Ward, 2000) and most likely reflects the relative absence of barriers to gene flow in the marine environment. Several factors may account for the homogeneity observed for the northern shrimp in the present study. The geographic distribution of this species in the Northwest Atlantic, although characterised by aggregations of commercial importance, is continuous in the deep waters at approximately $300-500 \mathrm{~m}$ from the northern tip of the Labrador Shelf to the portion of the Grand Bank north of the $46^{\circ} \mathrm{N}$ (Lilly et al., 1998). Similarly, within the Gulf of St. Lawrence, the species is continuously distributed from the Newfoundland coast to the Saguenay Fjord (Lambert et al., MS 1998). Such a distribution pattern favours gene flow. Furthermore, gene flow in P. borealis is most likely determined by the interaction between the duration of the pelagic larval stage and the circulation patterns observed in the Northwest Atlantic (Drinkwater and Mountain, 1997; Fig. 1). The 2-4 month duration of the larval phase provides a mechanism by which stocks can recruit from distant populations. The surface circulation patterns would favour such dispersion and subsequent homogenisation over large distances. In the Gulf of St. Lawrence, Ouellet et al., (1990) have shown that although the emergence of larvae takes place in areas corresponding to the main aggregations of adult shrimps, they are afterward dispersed by currents and exchanges may take place between aggregations. Pandalus borealis larvae are also broadly distributed along the Labrador coast and dispersion may also be caused by the circulation patterns in the area (Chaput, 1984). Gene flow does not need to be constant over time to prevent differentiation through random drift. Episodic events of expansion and shift in the geographic distribution of the aggregations of northern shrimp such as the ones that were observed recently in the Gulf of St. Lawrence (Lambert et al., MS 1998) and in the Labrador Sea (Parsons et al., MS 1999) may constitute a very efficient mechanism to increase gene flow among aggregations and prevent differentiation.

The results of the present study suggest that $P$. borealis does not form genetically distinct populations even over the large distance of the study area. Since there was generally no variation among maturity stages for most loci, it can also be assumed that the observed genetic patterns are temporally stable. However, there are a number of limitations to the present study. Our conclusions are based on a single survey and the analyses were carried out using a single analytical tool, electrophoresis of enzymes, that is an indirect indicator of genetic variation and detects only a small fraction of the variation at protein loci. Some areas of the species distribution such as the Scotian Shelf, the Gulf of Maine and Davis Strait were not sampled. Additional studies will be necessary to further test the general hypothesis of genetic homogeneity in the northern shrimp and to describe further the possible interaction between some areas such as the Gulf of St. Lawrence and the Labrador Sea populations. These studies should also test the possibility of differentiation on broader scales. Estimating the importance of exchanges between the Northeast Atlantic and the Labrador Sea populations may also have important implications for the management of this species. As suggested by Ward (2000), various molecular tools should be used whenever possible.

\section{Acknowledgements}

The authors thank Éric Parent, Geneviève Ross and Stéphane Lévesque for laboratory analysis and Diane Archambault, Louise Nadon and the scientific staff of the NGCC Alfred Needler and the Gadus Atlantica for the collection of samples. The authors also thank André Talbot and two anonymous reviewers for their constructive comments. This research was supported by the Department of Fisheries and Oceans, Canada.

\section{References}

BOHONAK, A. J. 1999. Dispersal, gene flow, and population structure. The Quarterly Rev. Biol., 74: 21-45.

CAVALLI-SFORZA, L. L., and A. W. F. EDWARDS. 1967. Phylogenetic analysis: models and estimation 
procedures. Evolution, 21: 550-570.

CARVALHO, G. R., and L. HAUSER. 1995. Molecular genetics and the stock concept in fisheries. In: Molecular genetics in fisheries. G. R. Carvalho and T. J. Pitcher (eds.). Chapman \& Hall, London, p. 55-79.

CHAPUT, G. J. 1984. Distribution and abundance of decapod larvae from Labrador with special emphasis on the distribution, abundance, development and growth of Pandalus borealis. Report to the Department of Fisheries and Oceans, St. John's, Canada.

DAVID, P., M.-A. PERDIEU, A. F. PERNOT, and P. JARNE. 1997. Fine-grained spatial and temporal population genetic structure in the marine bivalve Spisula ovalis. Evolution, 51: 1318-1322.

DRINKWATER, K. F., and D. G. MOUNTAIN. 1997. Climate and oceanography. In: Northwest Atlantic groundfish: Perspectives on a fishery collapse. J. Boreman, B. S. Nakashima, J. A. Wilson, and R. L. Kendall (eds.). American Fisheries Society, Bethesda, Maryland, p. 3-25.

GREGORIUS, H.-R. 1980. The probability of losing an allele when diploid genotypes are sampled. Biometrics, 36: 643-652.

HEBERT, P., and M. BEATON. 1989. Methodologies for allozyme analysis using cellulose acetate. Practical handbook. Educational service of Helena labs. 31 p.

HUBER, 1987. Phenotypic assortative mating and genetic population structure in the crab Trapezia digitalis. Mar. Biol., 93: 509-515.

IVANOV, B. G. 1972. Geographic distribution of the Northern shrimp, Pandalus borealis Kr. (Crustacea, Decapoda). Proc. Nat. Shelf. Ass., 62: 9-14.

JÓNSDÓTTIR, Ó. B. D., A. K. IMSLAND, and G. NEAVDAL. 1998. Population genetic studies of northern shrimp, Pandalus borealis, in Icelandic waters and the Denmark Strait. Can. J. Fish. Aquat. Sci., 55: 770-780.

KARTAVTSEV, Y. P. 1994. Wide-scale genetic differentiation among pink shrimp Pandalus borealis populations In: Genetics and evolution of aquatic organisms. A. R. Beaumont (ed.). Chapman \& Hall, London. p. 41-51.

KARTAVTSEV, Y. P, B. I. BERENBOIM, and K. I. ZGUROVSKY. 1991. Population genetic differentiation of the pink shrimp Pandalus borealis Kroyer, 1838, from the Barents and the Bering Seas. J. Shellfish Res., 10: 33-339.

KARTAVTSEV, Y. P, K. I. ZGUROVSKY, and Z. M. FEDINA. 1993. Spatial structure of the pink shrimp Pandalus borealis Kroyer 1838, from the Far-Eastern Seas as proved by methods of population genetics and morphometrics. J. Shellfish Res., 12: 81-87.

LAMBERT, J., H. BOUCHARD, and L. SAVARD. MS 1998. État des populations de crevettes nordiques (Pandalus borealis) de l'estuaire et du golfe du Saint-Laurent (divisions 4RST de l'OPANO). Can. Stock Ass. Sec. Res. Doc., No. 102, 34 p.

LI, G., and D. HEDGECOCK. 1998. Genetic heterogeneity, detected by PCR-SSCP, among samples of larval Pacific oysters (Crassostrea gigas) supports the hypothesis of large variance in reproductive success. Can. J. Fish. Aquat. Sci., 55: 1025-1033.

LILLY, G.R., D. G. PARSONS, and P.J. VEITCH. 1998. Spatial structure of northern shrimp (Pandalus borealis) off Labrador and eastern Newfoundland (Northwest Atlantic). In: Proceedings of the North Pacific Symposium on Invertebrate Stock Assessment and Management. G. S. Jamieson and A. Campbell (eds.). Can. Spec. Publ. Fish. Aquat. Sci., 125: 265-271.

McCRARY, J. A. 1971. Sternal spines as a characteristic for differentiating between females of some Pandalidae. $J$. Fish. Res. Board Can., 28: 98-100.

McELROY, D., P. MORAN, E. BERMINGHAM, and I. KORNFIELD. 1992. REAP: An integrated environment for the manipulation and phylogenetic analysis of restriction data. J. Hered., 83: 157-158.

MURPHY, R. W., J. W. SITES, Jr., D. G. BUTH, and C. H. HAUFERR. 1990. Proteins I: Isozyme electrophoresis. In: Molecular systematics. D. M. Hillis and C. Moritz (eds). Sinauer Associates, Inc. Sunderland, Massachusetts, U.S.A., p. 45-126.

NEI, M. 1978. Estimation of heterozygosity and genetic distance from a small number of individuals. Genetics, 89: $583-590$.

ORNSTEIN, L. 1964. Disc electrophoresis. I. Background and theory. Ann. N.Y. Acad. Sci., 121: 321-349.

OUELLET, P., D. LEFAIVRE, and V. KOUTITONSKI. 1990. Distribution of shrimp (Pandalus borealis) larvae and hydrographic pattern in the northern Gulf of St.Lawrence. Can. J. Fish. Aquat. Sci., 47: 2068-2078.

PARSONS, D. G., and J. FRECHETTE. 1989. Fisheries for northern shrimp (Pandalus borealis) in the Northwest Atlantic from Greenland to the Gulf of Maine. In: Marine invertebrate fisheries: their assessment and management. J. F. Caddy (ed). p. 63-85.

PARSONS, D. G., P. J. VEITCH, and G. T. EVANS. MS 1999. Resource status of northern shrimp (Pandalus borealis) off Baffin Island, Labrador and northeastern Newfoundland - second interim review. Can. Stock Ass. Sec. Res. Doc., No. 112, 53 p.

RASMUSSEN, B. 1953. On the geographic variation on growth and sexual development of the deep sea prawn (Pandalus borealis Kroyer). Fiskeridir. Skr. Havunders., 10: 1-160.

RICE, W. R. 1989. Analyzing tables of statistical tests. Evolution, 43: 233-235.

ROBY, D., J. D. LAMBERT, and J. M. SÉVIGNY. 1991. Morphometric and electrophoretic approaches to discrimination of capelin (Mallotus villosus) populations in the Estuary and Gulf of St. Lawrence. Can. J. Fish. Aquat. Sci., 48: 2040-2050.

ROFF, D.A., and P. BENTZEN. 1989. The statistical analysis of mitochondrial DNA polymorphisms: $\chi^{2}$ and the problem of small samples. Mol. Biol. Evol., 6: 539-545.

SAVARD, L. MS 1989. Evaluation des concentrations de crevettes (Pandalus borealis) du golfe du Saint-Laurent. CSCPCA Doc. Rech., No. 7, 71 p.

SAVARD, L., S. HURTUBISE, and J.-M. SÉVIGNY. MS 1993. Les nouvelles unités de gestion de la pêche à la 
crevette nordique (Pandalus borealis) dans le nord du Golfe du Saint-Laurent. DFO Atl. Fish. Res. Doc., No. $21,32 \mathrm{p}$.

SEEB, L. W., J. E. SEEB, and J. L. POLOVINA. 1990. Genetic variation in highly exploited spiny lobster Panulirus marginatus populations from the Hawaiian archipelago. Fish. Bull., 88: 713-718.

SÉVIGNY, J.-M. 1994. Variation génétique chez le flétan du Groenland (Reinhardtius hippoglossoides) et la crevette nordique (Pandalus borealis) du fjord du Saguenay. In: Le fjord du Saguenay: un milieu exceptionnel de reherche. J.-M. Sévigny and C. Couillard (eds.). Rapp. manus. can. sci. halieut. aquat., 2270: 50-62.

SHAKLEE, J. B., and BENTZEN, P. 1998. Genetic identificantion of stocks of marine fish and shellfish. Bull. Mar. Sci., 62: 589-621.

SHUMWAY, S. E., H. C. PERKINS, D. F. SCHICK, and A. P. STICKNEY. 1985. Synopsis of biological data on the pink shrimps, Pandalus borealis Krøyer, 1838. NOAA Tech. Rep. NMSFK 30, FAO Fisheries Synopsis No. 144.

SIN, F. Y. T., and M. B. JONES. 1983. Enzyme variation in marine and estuarine populations of a mud crab, Macrophthalmus hirtipes (Ocypodidae). New Zealand J. Mar. Freshwater Res., 17: 367-372.

SLATKIN, M. 1985. Rare alleles as indicator of gene flow.
Evolution, 39: 53-65.

SQUIRES, H. J. 1992. Recognition of Pandalus eous Makarov, 1935, as a Pacific species not a variety of the Atlantic Pandalus borealis Kroyer, 1838 (Decapoda, Caridaea).Crustaceana, 63: 257-262.

SOKOLOV, V. J. 1997. Variability of deep sea prawn Pandalus boreali (Crustacea, Decopoda, Pandalidae). Zoological Journal, 76: 281-286.

SWOFFORD, D. L., and R. B. SELANDER. 1989. A computer program for the analysis of allelic variation in population genetics and biochemical systematics (release 1.7). D.L. Swofford, Illinois Natural History survey.

WARD, R. D. 2000. Genetics in fisheries management. Hydrobiologia, 420: 191-201.

WHITMORE, D. H. 1990. Isoelectric focusing of proteins. In: Electrophoretic and isoelectric focusing techniques in fisheries management. D. H. Whitmore (ed.). CRS Press, Boca Raton, Florida, p. 81-105.

WORKMAN, P., and J. D. NISWANDER. 1970. Population studies of southwestern Indian tribes. II. Local genetic differentiation in the Papago. Amer. J. Hum. Gen., 22: 24-29.

WRIGHT, S. 1978. Evolution and the genetics of populations. Vol. 4: Variability within and among populations. The University of Chicago Press. Chicago and London, 580 p. 
